\title{
Review on the Role of Biological Nitrogen Fixation in the Environmental Terms
}

\author{
Diptimayee Dash $^{1^{*}}$ and Sonali Deole ${ }^{2}$ \\ ${ }^{1}$ Department of Agricultural Microbiology, College of Agriculture, Indira Gandhi \\ KrishiVishwa Vidyalaya, Raipur, India \\ ${ }^{2}$ Department of Entomology, College of Agriculture, Indira Gandhi KrishiVishwa Vidyalaya, \\ Raipur, India \\ *Corresponding author
}

\section{Keywords}

Biological nitrogen fixation, Rhizobium, soil fertility and nitrogen economy

Article Info

Accepted:

22 July 2019

Available Online:

10 August 2019

\section{A B S T R A C T}

Biologically active product more appropriately called as "microbial inoculants" contains active strength of selective microorganisms like bacteria, algae, fungi; alone or in combination helps in increasing crop productivity by biological nitrogen fixation. Biological nitrogen fixation, the second most important biological process on earth after photosynthesis involves conversion of atmospheric nitrogen (N2) to ammonium, a form of nitrogen that can be utilized by plants The rhizobia are a group of Gram-negative bacteria that form speciesspecific symbioses with legume plant. The Rhizobium-legume symbiosis is superior to other nitrogen fixing systems as symbiotic nitrogen fixation is an important source of nitrogen, and the various legume crops and pasture species often fix as much as 200 to $300 \mathrm{~kg}$ nitrogen per hectare. Thus emphasis should be given for establishment of efficient symbiotic N2-fixing systems in legumes. The work pertaining to different aspects on legume - Rhizobium symbiosis have been covered in the review. Biological nitrogen fixation is estimated to be approximately 150 to 200 million tonnes annually on the earth's surface. Biological nitrogen fixation contributes about 100 million tons of nitrogen for terrestrial ecosystems, 30 to 300 million tons for marine ecosystems and 20 million tons from chemical fixation due to atmospheric phenomena. Besides the unique nature of association, the importance of the association from the point of view of nitrogen economy and soil fertility also seems to have generated so much interest on the subject within the scientific community. Most researches' results indicate that Rhizobium inoculation is promising biofertilizer because it is cheap, easy to handle and improves plant growth. Therefore, legume-rhizobia symbiosis can provide easy and inexpensive way to enhance soil fertility and improve crop production. 


\section{Introduction}

The association of rhizobia with leguminous plants is one of the most thoroughly studied subjects in the biological sciences. $\mathrm{N}_{2}$ - fixing ability of rhizobia has resulted in their use as biofertilizers and hence they have received more attention now a days. Besides the unique nature of association, the importance of the association from the point of view of nitrogen economy and soil fertility also seems to have generated so much interest on the subject within the scientific community. The work pertaining to above different aspects on legume - Rhizobium symbiosis have been covered in the review.

\section{Importance of $\mathrm{BNF}$ in legumes}

An exponential rise in world population indicates the need for increased crop production. Chemical nitrogen fertilizers will continue to serve for increasing grain production until a predictable future, but efforts should also be oriented towards augmenting biological nitrogen fixation. Biologically active product more appropriately called as "microbial inoculants" contains active strength of selective microorganisms like bacteria, algae, fungi; alone or in combination helps in increasing crop productivity by biological nitrogen fixation. Legumes have long been recognized and valued as "soil building" crops. Most legumes can obtain between 50 and $80 \%$ of their total nitrogen requirements through biological fixation. By contrast, the legume has been characterized as being less responsive to the application of fertilizer $\mathrm{N}$; the fertilizer efficiency for legumes generally ranges from 20 to 50\%. (Mengel et al., 1987). It is in this context, the use of the nitrogen fixing bacteria in agricultural practices is gaining importance (Baker, 1992). Hardarson et al., (1993) reported that the root nodule rhizobia approximately reduce 20 million tons of atmospheric nitrogen to ammonia which is $50 \%-70 \%$ of the world biological nitrogen fixation.

The rhizobia are a group of Gram-negative bacteria that form species-specific symbioses with legume plant, Nitrogen fixation, the reduction of atmospheric dinitrogen (N2) to ammonia (NH3), by rhizobia only occurs during symbiosis and provides a significant proportion of available nitrogen in the biosphere. The reduction of atmospheric nitrogen into ammonia is the second most important biological process on earth after photosynthesis (Sylvia, 2005). The Rhizobium-legume symbiosis is superior to other nitrogen fixing systems due to its high potential. Thus emphasis should be given for establishment of efficient symbiotic $\mathrm{N}_{2}$-fixing systems in legumes. Symbiotic nitrogen fixation is therefore of great ecological and socio-economic importance (Sanaa and Fawziah, 2005).

Peoples et al., (1995) reported that the symbiotic nitrogen fixation is an important source of nitrogen, and the various legume crops and pasture species often fix as much as 200 to $300 \mathrm{~kg}$ nitrogen per hectare. Globally, symbiotic nitrogen fixation has been estimated to amount to at least 70 million metric tons of nitrogen per year (Brockwell et al., 1995). He reported that the rhizobia in root nodules are estimated to carry out between $50-70 \%$ of the world'sbiological nitrogen fixation and the estimated annual biologicalfixation of atmospheric nitrogen varies between $100 \times 10^{6}$ and $180 \times 10^{6} \mathrm{Mt}$ per year.

Peoples et al., (1995) described that the rhizobia are of great importance for nitrogen acquisition through symbiotic nitrogen fixation in a wide variety of leguminous plants. Plants benefit from nitrogen-fixing bacteria when the bacteria die and release 
nitrogen to the environment or when the bacteria live in close association with the plant. In legumes, the bacteria live in small growth on the root called nodule. Within these nodules, nitrogen fixation is done by the bacteria and the $\mathrm{NH}_{3}$ produced is being absorbed by the plant.

Biological nitrogen fixation is estimated to be approximately 150 to 200 million tonnes annually on the earth's surface. The symbiotic relationships between specific soil microorganisms and plants are the most significant contributor of $\mathrm{BNF}$ in most terrestrial ecosystems. Biological nitrogen fixation involves conversion of atmospheric nitrogen $\left(\mathrm{N}_{2}\right)$ to ammonium, a form of nitrogen that can be utilized by plants (Vessey et al., 2003). Rakash and Rana (2013) reported that the biological nitrogen fixation contributes about 100 million tons of nitrogen for terrestrial ecosystems, 30 to 300 million tons for marine ecosystems and 20 million tons from chemical fixation due to atmospheric phenomena.

Roychowdhury et al., (2013) reported that the legume-rhizobial symbiosis has a large impact on success of legumes hence the atmospheric nitrogen the organisms fix can be more than the fertilizer nitrogen an average farmer can afford to buy and apply. Therefore, legumerhizobia symbiosis can provide easy and inexpensive way to enhance soil fertility and improve crop production.

\section{Effect of biological $\mathrm{N}_{2}$ fixation on soil $\mathrm{N}$ balance}

In addition to the utilization of fixed $\mathrm{N}_{2}$, the uptake of soil nitrogen was also reported to be more in nodulated and $\mathrm{N}_{2}$-fixing soybean plants than in case of non-nodulated control plants (Jensen and Sorensen, 1988). Similar observations were reported in case of groundnut (Voandzeia subterranea) where plants inoculated with rhizobia accumulated significantly more $\mathrm{N}$ than that in case of mineral nitrogen supplied control plants (Brooks et al., 1988).

Similarly, for soybean grown with different starter $\mathrm{N}$ levels after rice which received different fertilization levels, the $\mathrm{N}$ balances with seed and stover removed ranged from 12 to $-35 \mathrm{~kg} \mathrm{ha}^{-1}$ in northern Thailand (Jefing et al., 1992).But positive $\mathrm{N}$ balances of upto $136 \mathrm{~kg} \mathrm{ha}{ }^{-1}$ for several legume crops following seed harvest had been shown by Peoples and Crasswell (1992). However, with crop residues removed from the field the net $\mathrm{N}$ balances for groundnut were -27 to -95 , for soybean -28 to -104 , common bean -28 , green gram -24 to -65 and cowpea -25 to $-69 \mathrm{~kg} \mathrm{ha}^{-1}$ (Wani et al., 1995). Net nitrogen balances calculated for different cultivars of pigeonpea and chickpea grown at Patancheru and Gwalior respectively indicated that all studied varieties depleted soil nitrogen (Wani et al., 1995).

Sharma and Upadhyay (2001) observed that seed inoculation influenced the plant height and dry matter accumulation at all stages of crop growth. Being an important kharif legume, urdbean, Vigna mungo (L.) fixes atmospheric nitrogen and improves the soil fertility. Black gram can obtain nitrogen by atmospheric fixation in their root nodules in symbiosis with soil rhizobia and thus has a potential to yield well in nitrogen deficit soils. A legume plant having effective root nodules not only can meet its own nitrogen requirement but also enrich the soil nitrogen content, thereby improving soil fertility and sustainability (Kannaiyan2002). BNF offers an economically attractive and ecologically sound means of reducing external $\mathrm{N}$ input. It contributes to the replenishment of soil $\mathrm{N}$, and reduces the need for industrial $\mathrm{N}$ fertilizers (Larnier et al., 2005). 
It is widely believed that legumes improve soil fertility because of their $\mathrm{N}_{2}$-fixing ability. However, in order to assess the role of biological nitrogen fixation in the sustainability of different cropping systems, in addition to the amount of $\mathrm{N}_{2}$ fixed by the component legume crop the overall nitrogen balance of the system needs to be considered. Biological nitrogen fixation contributes to the replenishment of soil $\mathrm{N}$, and reduces the need for industrial $\mathrm{N}$ fertilizers (Larnier et al., 2005). It offers an economically attractive and ecologically sound means of reducing external $\mathrm{N}$ input. Inoculated treatments showed significant increase in the total $\mathrm{N}$ content of soil over control. The highest increase in soil N 22.91 per cent over control was recorded in case of SB-16. (Patra et al., 2008).

Most researches results indicate that Rhizobium inoculation is promising biofertilizer because it is cheap, easy to handle and improves plant growth. Akhtar et al., (2012) reported that Rhizobium and Azotobacter significantly increased the lentil plant biomass (27.67g/pot), number of nodules (68.6/plant), nodular mass (1.95 $\mathrm{g} /$ plant $)$, root length $(39 \mathrm{~cm})$, shoot length $(26.3 \mathrm{~cm})$, root weight $(7.2 \mathrm{~g} / \mathrm{pot})$ and shoot weight $(6.8 \mathrm{~g} / \mathrm{pot})$ at full dose of fertilizer. Biomass yield with Rhizobium (27.13 g/pot) Chemical analysis of plant matter showed significantly high value of nitrogen $(4.4 \%)$ due to co-inoculation followed by Rhizobium alone $(4.21 \%)$ at full dose of fertilizer. The use of legume species is of great importance because they may provide nitrogen to the system through $\mathrm{N} 2$ fixation and supply nitrogen without the application of mineral fertilizers (Berger et al., 2013).

Saleh et al., (2013) studied the effect of three Rhizobium strains isolated from different species of legumes (RLc107 from lentil, RCa 220 from chick pea and RVm 307 from black gram) on nodulation of two black gram varieties. Rhizobium inoculation improved nodulation in both the varieties than that of uninoculated control. The highest value for nodule number (58.45) per plant, nodule fresh weight $(46.11 \mathrm{mg})$ per plant and nodule dry weight $(12.07 \mathrm{mg})$ per plant were observed in BINA MASH-1 when inoculated with Rhizobium strain RVm 307. Therefore, legume-rhizobia symbiosis can provide easy and inexpensive way to enhance soil fertility and improve crop production (Roychowdhury et al., 2013). As per Lalitha and Sam Immanuel, 2013 Microbial inoculation induced significant changes in soil characteristics. Inoculation in black gram and green gram significantly enhanced the $\mathrm{N}$ (180, $170 \mathrm{mg} / \mathrm{Kg}$ soil $), \mathrm{P}(6,8.2 \mathrm{mg} / \mathrm{Kg}$ soil $)$ content of the soil and $\mathrm{K}(171,188 \mathrm{mg} / \mathrm{Kg}$ soil).

\section{References}

Akhtar, N., Qureshi, M. A., Iqbal, A., Ahmad, M. J. and Khan, K. H. 2012. Influence of Azotobacter and IAA on Symbiotic Performance of Rhizobium and Parameters of Lentil. J.Agric.Res., 50(3): 224-229.

Baker D D, Mullin B C. 1992. Actinorhizal symbioses. In: Stacey G, Burris R H, Evans H J, editors. Biological nitrogen fixation. New York, N.Y: Chapman \& Hall; pp. 259-292.

Bhagat, P. K., Dash, D., Raj, A. and Jhariya, M. K. 2014. Effect of Rhizobium inoculation on growth and biomass accumulation in Leucaena leucocephala. In The Ecoscan V, 65-74.

Brockwell, J., Bottomley, P.J. and Thies, J.E. 1995. Manipulation of rhizobia microflora for improving legume productivity and soil fertility: a critical assessment. Plant Soil, 174:143-180.

Brooks, C.B., Dadson, R.B. and Green, B.M. 1988. Evaluation of symbiotic 
effectiveness of elite and wild strains of Bradyrhizobium on cultivars of Voandzeia subterranea (L.) Thouars. Trop. Agric., 65: 61-63.

Dash, D., Pattainayak, S. K., Jena, M. K. and Nayak, R. K. 2000. Effect of seed treatment of green gram with different doses of molybdnum and cobalt on seed yield, biomass production and their incorporation as partial green manure crop to benefit subsequent maize crop in sequence. Int. J. Tropical Agriculture, 18(2): 101-111.

Hardarson, G., Bliss, F.A., Cigales-Rivero, M., Henson, R.A., Kipe-Nolt, J.A., Longeri, L., Manrique, A., PenaCabriales, J., Pereira, P.A.A. and Sanabria, C. 1993. Genotypic Variation in Biological Nitrogen Fixation by Common Bean. Plant and Soil, 152: 5970.

Jefing, Y., Herridge, D.F., Peoples, M.B. and Rerkasem, B. 1992. Effects of N fertilization on $\mathrm{N} 2$ fixation and $\mathrm{N}$ balances of soybean grown after lowland rice. Plant Soil., 147: 235-242.

Jensen, E.S. and Sorensen, L.H. 1988. Uptake of soil nitrogen by soybean as influenced by symbiotic N2-fixation or fertilizer nitrogen supply. Soil Biol. Biochem., 20: 921-925.

Kannaiyan, S. 2002. Biofertilizers for sustainable crop production. In Biotech. Biofert. (Kannaiyan, S., ed.). Narosa Publishing House, New Delhi, India, p. 9-49.

Kumar, A., Dash, D. and Jhariya, M. K. 2013. Impact of Rhizobium on growth, biomass accumulation and nodulation in Dalbergia sissoo seedlings. An Int. J. of Life Sci., The Bioscan, 8(2): 553-560.

Lalitha, S. and Immanuel, S. P. 2013. Biochemical characterization of Rhizobium and its impact on black gram and green gram plants. Int $\mathbf{J}$. Current Sci., 9 E: 1-6.
Larnier, J.E., Jordan, D.L., Speras, F.J., Wells, R. and Johnson, P.D. 2005. Peanut response to inoculation and nitrogen fertilizer. Agron. J., 97: 79-84.

Mengel, D.B., Segars, W. and Rehm, G.W. 1987. Soil fertility and liming. In: Wilcox, J.R.ed. Soybeans: Improvement, production and uses. 2nd edition. Am. Soc. Agron. Madison, W.I., p. 461-496.

Patra, R. K., Pant, L.M. and Rath, B.S. 2010. Nodulation Characteristics of Soyabean Rhizobial strains in relation to their $\mathrm{N}$ fixing ability. Env. \& Ecology., 28 (2): 1089-1092.

Pattainayak, S. K., Dash, D., Jena, M. K. and Nayak, R. K. 2000. Seed treatment of green gram with molybdnum and cobalt: Effect on nodulation, biomass production and $\mathrm{N}$ uptake in an acid soil. J. of Indian Soc. Of Soil Sci., 48(4) 769773.

Peoples, M.B. and Craswell, E.T. 1992. Biological nitrogen fixation: investments, expectations, and actual contributions to agriculture. Plant Soil., 141: 13- 39.

Peoples, M.B. and Craswell, E.T. 1992. Biological nitrogen fixation: investments, expectations, and actual contributions to agriculture. Plant Soil., 141: 13- 39.

Peoples, M.B., Herridge, D.F., and Lahda, J.K. 1995. Biological nitrogen fixation: an efficient source of nitrogen for sustainable agricultural production. Plant Soil, 174:3-28.

Rakash, N. and Rana, K. 2013. Food Legumes for Livelihood and Nutritional Security in North Eastern Himalayan Region: Prospects and Constraints. Indian J. of Agricultural Sci., 83: 899906.

Roychowdhury, R., Banerjee, U., Sofkova, S. and Tah, J. 2013. Organic farming for crop improvement and sustainable 
agriculture in the Era of Climate Change. Journal of Biological Sciences, 13: 50-65.

Saleh, M.A., Zaman, S. and Kabir G., 2013. Nodulation of black gram as influenced by Rhizobium inoculation using different types of adhesive. Nature and science, 11(7): 241-245.

Saleh, M.A., Zaman, S. and Kabir, G. 2013. Yield Response of Black Gram to Inoculation by Different Rhizobium Strains using Various Types of Adhesives. Asian J.of Biological Sci., 6(3):181-186.

Salve, P.B. and Gangwanae, L.V.1992. Rhizobium from wild legumes and nitrogen fixation in ground nut. In: Biofertilizers Technology Transfers Associated Publications Co., New Delhi, p. 95-100.

Sanaa, M.E.D. and Fawziah, S.A.S. 2005. Role of some chemical compounds on the detoxification of Rhizobium leguminosarum biovar vicia by some Heavy Metals. Pak.J. Biol. Sci., 8: 1693-1698.
Sharma, S. and Upadhayay, R.G., 2001. Effect of seed inoculation with various Bradirhizobium strains on growth and yield attributes of mungbean (Vigna radiate L. Wilczek). Legumes Res., 26(3): 211-214.

Sylvia, D.M., Fuhrmann, J.J., Hartel, P.G. and Zuberer, D.A. (2005). Principles and Applications of Soil Microbiology. 2nd Edition. p. 373 - 404.

Vessey, J.K. 2003. Plant growth promoting rhizobacteria as biofertilizers. Plant Soil, 255: 571-86.

Wani, P.A., Zaidi, A., Khan, A. A. and Khan, M. S. 2005. Effect of phorate on phosphate solubilization and indole acetic acid releasing potentials of rhizospheric microorganisms. Annals of Plant Protection Sciences. 13(1):139144.

Wani, S.P.; Rupela, O.P. and Lee, K.K. 1995. Sustainable agriculture in the semiarid tropics through biological nitrogen fixation in grain legumes. Plant Soil., 174: 29-49.

\section{How to cite this article:}

Diptimayee Dash and Sonali Deole. 2019. Review on the Role of Biological Nitrogen Fixation in the Environmental Terms. Int.J.Curr.Microbiol.App.Sci. 8(08): 2660-2665. doi: https://doi.org/10.20546/ijcmas.2019.808.308 